\title{
The Internationalization of Doctoral Social Work Education: Learning from a Partnership in Ethiopia
}

\author{
Alice K.Johnson Butterfield
}

\begin{abstract}
What does it mean to internationalize doctoral education by working abroad? What does it mean to internationalize doctoral education in one's home country? This article offers a perspective based on the Social Work Education in Ethiopia Partnership, which established Ethiopia's first-ever master's degree in social work in 2004. To ensure sustainability of the MSW program, a doctoral program in Social Work and Social Development was launched in 2006. This article describes the devel opment and research base of the doctoral program. Beginning in the first semester, teams of doctoral students join with poor communities in action research. Overall, these efforts lead to an emerging model of university-based development. Through engaged action research, faculty and students use human capital resources and the educational process to function as "development actors." Some ideas for internationalizing doctoral education are offered. Deans and directors in the United States and Canada are challenged to expand doctoral education within a developing country and to prepare doctoral students to includeinternational perspectives in their teaching and research.
\end{abstract}

Keywords: Doctoral education, international, community development, higher education partnerships, action research

\section{INTRODUCTION}

International social work is a two-way street. This phrase illustrates that there is much that social workers in the developed world can learn from social work in developing countries (Midgley, 1990). This idea guides my work internationally and represents what I believe should be the ultimate goal of international social work. But, how do we and others cross theintersections of the world and bring each other to our side of the world in ways that promotemutual learning and development? In translating these words to the theme of internationalizing doctoral social work education, two questions emerge. What does it mean to internationalize doctoral education by working abroad? What does it mean to internationalize doctoral education at our home universities?

Alice K. Johnson Butterfield is professor, Jane Addams College of Social Work, University of Illinois at Chicago, Chicago, IL 60411. 
In the history of international social work, there are critiques of Western models that have been imposed on curriculum in developing nations, such as Africa, and earlier in India and elsewhere (Healy, Asamoah, \& Hokenstad, 2003). I would like to posit, however, that we are in a new global environment defined by the information age - a concept articulated by Thomas Friedman (2006) as "the world is flat." In a world with fewer trade and political barriers, billions of people are instantly "connected" to one another through the Internet and advances in digital communication. In this environment of horizontal relationships, global collaboration takes on new meaning: International social work education partnerships can be ways of sharing methods, skills, models, and innovative practices without imposing them on developing countries in a fashion reminiscent of colonialism.

To provide an example of what it means to internationalize doctoral education by working abroad, I will share experiences and involvement at both the master's and doctoral levels in Ethiopia. What I have learned about the internationalization of doctoral education has been learned through this practice. My thoughts are based particularly on my work and that of my colleagues at the Jane Addams College of Social Work at the University of I Ilinois at Chicago and the GraduateSchool of Social Work at Addis Ababa University in Ethiopia through our university-to-university partnership. Based on a formal agreement committing our two universities to joint efforts in teaching, service, and research, we envisioned that our partnership could become a "development actor." Holding fast to the idea that international social work is a two-way street, we imagined that the major efforts of our development, which occurred through our partnership, would occur in Ethiopia. Over time, its deliverable products-new degree granting programs, a professional workforce, and applied research-together would build the overall capacity of the host country to deal more adequately with its social and health problems.

\section{SOCIAL WORK EDUCATION IN ETHIOPIAPARTNERSHIP (PROJECT SWEEP)}

The story starts with an e-mail message inviting me to travel to Ethiopia with a group of medical faculty. In May 2001, I went to Ethiopia as a member of a delegation led by former Ambassador to Ethiopia David H. Shinn. The purpose of our visit was to identify specific needs and opportunities for collaboration with university and government officials and leaders of local non-governmental organizations (NGOs) working in community health and social service delivery (Shinn, 2001). I was particularly interested in the role of social work in Ethiopia. What was the need for social work? Did the profession exist? I found that the previous military regime had ended social work education. Prior to 1976, there was a vibrant school of social work offering a bachelor's degree. Some 30 years later, only a remnant of social work education remained. Two former deans, Dr. Seyoum Gebre Selassie and Dr. Andargatchew Tesfaye, both whom received their Ph.D. in social work and sociology from the University of Michigan in the early 1970s, had "hidden" six courses in macro social work within the undergraduate curriculum at Addis Ababa University (AAU). In the practice field, less than 50 social workers with bachelor's degrees remained where they had practiced social work in Ethiopia for approximately the last 30. Although most were ending their careers through retire- 
ment and several were recently deceased, these social workers were leaders in NGOs and had mentored many graduates of sociology in the ways of social work. Also, Drs. Seyoum and Andargatchew, and a few younger colleagues in the Department of Sociology and Social Anthropology, had successfully placed the development of a master's degree in social work in the University's five-year strategic plan. While a goal, there was little or no capacity to actually develop such a program.

Together, we wrote a proposal for seed funds to Higher Education for Development (HED), the intermediary organization established in 1992 as the Association Liaison Office for University Cooperation in Development (ALO). HED assists the nation's six major higher education associations in partnering with the U.S. Agency for International Development (USAID). HED has funded more than 250 university-to-university partnerships over the past five years, from education, law, agriculture, and other disciplines, but we were the first social work program to receive funding. The Jane Addams College received $\$ 99,000$ to partner with Addis Ababa University to establish Ethiopia's first-ever master's degree in social work. Through the Social Work Education in Ethiopia Partnership (Project SWEEP), we completed an assessment of needs and planning, curriculum development and faculty exchange, and program development, including syllabi and teaching materials [http://www.aboutsweep.org]. A five-year Memorandum of Agreement was signed by the two universities to collaborate in teaching, research, and service.

In developing the new master's degree curriculum, we aligned it with the "Global Standards for Social Work Education and Training" (IASSW, 2004). The curriculum addresses Ethiopia's current and emerging health and social needs by emphasizing engaged research and community-based services that focus on poverty reduction. The new graduate degree prepares professional social workers to manage community-based services and develop new programs in the areas of health, child welfare, and community development. Specific courses focus on community practice, social mobilization, food security, and migration; poverty and gender discrimination; counselling for people infected with HIV/AIDS; and extended family support for orphaned and abandoned children. Project SWEEP lays the groundwork for developing Ethiopia's educational capacity for preparing a professional social work workforce. We also imagined that the establishment of the very first MSW program in Ethiopia would be a significant step toward the accomplishment of the Ethiopian government's long-range goal for reducing poverty. The Faculty Senate at AAU approved the curriculum and the new degree in 2004.

The UIC-AAU partnership has been extraordinarily successful (c.f., Johnson Butterfield \& Linsk, 2005). An indicator of this success is that AAU decided midproject to begin the graduate program as a new graduate school of social work, rather than as a master's degree in the Department of Sociology and Social Anthropology. In July 2006, the "first batch" (as they call themselves) of 39 students defended their thesis research projects and graduated with an MSW degree. The "second batch" of 39 students graduated in September 2007, and a new class of 32 students, one-third of whom are women, were enrolled. Applications have nearly doubled each year, from 60 applications to 109 applications to 210 applications in 2006 (third class of students). At the graduation celebration, which students organ- 
ized at the Hilton Hotel in Addis Ababa, remarks by the Minister of Capacity Building and Andreas Eshete', AAU's President and UNESCO Chair for Human Rights and Democracy heralded the new program as a major educational development and the most successful international partnership on the campus.

Our experience of success is also due to another phenomenon at work in some countries in Africa, such as Tanzania, Ethiopia, and Southern Sudan. In Ethiopia, for example, the government is expanding technical institutes to academic degree granting institutions and building 13 new public universities from the ground up. This includes expanding capacity at eight institutions, each projected to grow by $8,000-10,000$ students, plus the development of new universities, for a total of 21 institutions of higher education. This expansion also includes administrative improvements and quality education. To update pedagogical techniques, the university encourages faculty to move away from a strict lecture format to applied research, class exercises, group projects, internships, and other interactive methods. Project SWEEP is valued for fostering several innovations, including a skillsbased curriculum, block teaching for course scheduling, a transparent admissions process, intensive student orientation, an adult-learning approach, and new pedagogical methods, such as group projects and field placements. Our block-teaching method was born out of necessity and from our understanding of adult learning models. Since there were only two Ethiopian faculty (the dean and associate dean with other administrative responsibilities), faculty and colleagues from other universities throughout the world went to Ethiopia to teach for one-month periods, including classes scheduled during their summer vacations or mid-semester breaks. In the first year, for example, four one-month courses were taught each semester.

Another reason for the success of our partnership was the infusion of leadership from the AAU side of the partnership, with the appointment of Abye Tasse as Dean and Dr. Melese Getu as Associate Dean. Their leadership was essential in obtaining university approval, securing computers, classroom space, and administrative staff. Until the appointment of Dean Abye, our project functioned more as a "grassroots" initiative within the larger university. With leadership from President Andreas, and with Dean Abye also holding a key administrative position as Associate Vice President for International Affairs, Project SWEEP quickly turned into a recognized innovation and center of excellence within Addis Ababa University. This is a good example of how partnerships working at the "grassroots level" can become solidly a part of larger systems when leadership at the top joins grassroots initiatives.

\section{BUILDING CAPACITY AND SUSTAINABILITY}

The success of our partnership must also be assessed by its ability to accomplish two goals: 1) build capacity for dealing with social problems in Ethiopia and 2) sustain social work education at the university level over the long-term. To provide some context to these issues, this section provides a brief overview of the social, health, and economic context of Ethiopia. Restarting social work education was seen as part of the answer to social problems in the country. It was in the following context that we planned the MSW curriculum to build the capacity of social work 
in Ethiopia and work to develop the doctoral program to sustain social work education at the university.

\section{The Social, Health, and Economic Context of Ethiopia}

Ethiopia faces many problems. The situation in Ethiopia is not unlike that in many African countries. Ethiopia is an extremely poor country of 71 million people. Eighty-one percent of its population lives on less than \$2 USD per day. As first exposed in 1984 by cameraman Mohamed Amin, recurrent drought and famine continue to plague the country (Smith, 1998). Since the appearance of HIV/AIDS, life expectancy has fallen from 45 years in 1990 to 42 years in 2001. Approximately three million people have HIV/AIDS, the third largest number of any country in the world. An estimated 1.2 million Ethiopian children have been orphaned. "Orphans in Africa suffer recurrent psychological trauma, starting with the illness and death of their parents, followed by cycles of poverty, malnutrition, stigma, exploitation, and often, sexual abuse. Experiencing this, orphans are at risk of developing antisocial behavior patterns that can endanger community and national development" (Matshalaga \& Powell, 2002, p. 185-186). Impoverished grandparents care for many of these orphans, but as their numbers of grandparents decline, child-headed households are becoming more common. Child-headed households are a great risk, because of their limited economic capacity, gender inequality, prostitution, and drug and alcohol abuse.

In part, these problems result from morethan 30 years of war with Eritrea, which consumed the country's resources. Similar to countries in Eastern and Central Europe ruled by Communist or totalitarian regimes, Ethiopia was ruled by a military regime prior to the 1990s. About the same time that the Berlin Wall fell and revolutions occurred in former Communist-bloc countries, Ethiopia changed to a democratic government in 1991. The country is making progress towards a market economy through its Sustainable Development and Poverty Reduction Program (SDPRP), which gives regional states the responsibility to plan and implement the delivery of health and other human services. In terms of human development, Ethiopia's reform and decentralization program has made progress:

- Gross school enrollment increased from 33\% in 1990 to $64 \%$ in 2000 to $93 \%$ in 2005.

- GDP per capita grew from an average 5.4\% in 2000 to $8.7 \%$ in 2005.

- Infant mortality decreased from 128 per 1,000 live births in 1990 to 92 per 1,000 live births in 2000 to 80 per 1,000 live births in 2005 (World Bank, 2007).

These improvements indicate a good context for development, even though improvement has not been uniform and disparities have widened in different regions of Ethiopia between urban and rural areas and among various groups of the population. The high-risk groups who are less able to take advantage of democratization and economic growth are the large numbers of people living in poverty, including women and children, the elderly, the disabled, and the handicapped.

From the perspective of higher education, Ethiopia has lacked the professional infrastructure to address the problems discussed above. Thus, for many years, 
attempts to build a professional workforce meant sending people overseas for advanced degrees and training. Sending students to graduate programs in other countries does not build the capacity of local universities. This approach has proved at times to be disastrous, because of the high cost of education at overseas sites and the "brain drain" or "brain bleed," as some have called it. Doctoral students who study abroad too often remain there, and the resultant expatriate loss further reduces the opportunity for the country to build its own cadre of doctoraltrained faculty. The statistics are staggering. A survey at Addis Ababa University shows that 400 of 600 graduates who went for further study in the United States and Europe did not return to Ethiopia. Two out of 10 doctors from Addis Ababa University's medical faculty returned. Only $20 \%$ of the graduates of sociology and social administration who went for further study returned, and most were anthropologists who have a rich context for their work in Ethiopia. Although the Department sent several graduates abroad to obtain advanced degrees in social work in the late 1990s, none returned to provide leadership for developing the master's degree, as outlined in the University's strategic plan (Getu, 2005).

\section{ThePh.D. Program}

From the beginning of Project SWEEP, sustainability was an underlying concern of our planning team. "Sustainability is built on the capacity of the faculty." Those words by Professor Seyoum are etched in my mind and, from that point, our team's unspoken and ultimate goal was the development of a doctoral program in Ethiopia. This became our vision. Therefore, once the master's program was operational, attention returned to developing a doctoral program to prepare Ethiopian faculty for positions at Addis Ababa University and other universities in Ethiopia that may develop social work programs. With David Moxley, formerly of Wayne State University and now on the faculty of the University of Oklahoma, Abye Tasse and I collaborated on a grant proposal that was to be presented to the Ministry of Education for funds to start the Ph.D. program.

Eight students from the MSW class of 2006 were admitted to the doctoral program and hired as staff. Their roles included partial responsibilities for field education, scheduling and logistics for international visitors, student advising, assisting in strategic planning, administration of the Graduate School of Social Work, and so on. Thus, in the short-term, the doctoral program increased thecapacity for Ethiopians in residence by about $200 \%$. Addis Ababa University has also provided transportation funds and a small per diem for visiting international faculty, as well as funding for action research.

A challenge faced by the international team who developed the doctoral curriculum was combining their various views about what doctoral education should entail. The two Ethiopian members of our team had received doctorates from France and England; another professor obtained her doctorate in India; I had obtained mine in the United States. The British experience leaned toward individual work with a faculty chairperson and extensive individualized readings; the French experience included lively "discussion and debate" seminars with the great minds of the university; the program in India focused on applied research. My experience at Washington University in St. Louis involved interdisciplinary courses and research practicum. As we sought to create a plan for doctoral education in 
Ethiopia, each of us brought our biases to the table. We each hoped to incorporate some of what we felt were the strengths of our doctoral programs; each of us wanted to address some of what we felt were our program's shortcomings. We also knew that the new doctoral program had to address the difficult problems of Ethiopia and the urgent need for faculty. Moreover, from our various perspectives, we sought a way to streamline the doctoral educational process without compromising quality. Our work together became synergistic. We created a curriculum plan for the Ph.D. program in Social Work and Social Development at Addis Ababa University, which includes innovative elements borrowed from our international experiences but which is also shaped by the particular context and educational realities in Ethiopia.

Table 1 shows the year-round curriculum, which includes a menu of eight courses, nine seminars, and eight planning/ research units. Courses (for credit) are completed in the first four semesters of study. Seminars (pass/ fail), held by the resident or visiting faculty, include four doctoral pro-seminars that critically examine substantive topics, such as poverty, gender, community heath, homelessness, migration, urban and rural development, child welfare, criminal justice, and so on, through multi-disciplinary and interdisciplinary frameworks. Seminars engage faculty and students in dialogue and debate to critically analyze the topic of discussion, examine the theory and research base, and identify best practice models and policies for addressing it. A comprehensive portfolio is theanchor upon which the Qualifying Assessment is completed at the end of the fourth semester. Students who pass can move forward in doctoral study. Since coursework will be completed by the end of the first calendar year, students will be able to teach during the second calendar year of their studies.

The dissertation consists of three original empirical papers of publishable quality for submission to relevant journals. These articles are based on team-led action research projects but reflect a carve-out area of independent research carried out by each student. The three papers comprise an integrated series of scholarly publications that focus on a social issue of local, regional, or national importance. The final product, which documents the student's scholarly expertise, includes three additional sections: an introduction to the substantivearea of the research, implications for social work and social development, and a summary and conclusions. ThePh.D. program is a year-round course of study; thus, students will complete their dissertation projects and graduate in three years (c.f., Tasse \& Getu, 2006).

The planning/ research modules became the solution to another problem that we faced in developing the doctoral curriculum. How could we reduce delays in completing doctoral degrees and associated research projects? Without question, we wanted to avoid "credentializing" doctoral students, but at the same time, neither the urgent needs of the country nor the scarce resources of the university could afford extended financial and human resource investment in a few select students. We also wanted to do something different than the traditional process of doctoral education in the United States, where the typical trajectory towards a doctoral degree requires students to: 1 ) complete coursework; 2) pass a qualifying exam; 3) write and defend a proposal; 4) carry out research and analyze data; 5) write the dissertation; and 6) successfully defend it. I do not know the average length of time it 


\begin{tabular}{|c|c|c|c|}
\hline $\begin{array}{r}\text { Year 1: } \\
\text { Summer }\end{array}$ & $\begin{array}{l}\text { Year 1: Fall } \\
\text { Semester }\end{array}$ & $\begin{array}{c}\text { Year 1: Spring } \\
\text { Semester }\end{array}$ & Year 2: Summer \\
\hline $\begin{array}{l}\text { Models and } \\
\text { Theories of } \\
\text { Social Change } \\
\text { (C) } 2 \text { credits }\end{array}$ & $\begin{array}{l}\text { Doctoral Pro- } \\
\text { Seminar I (S) }\end{array}$ & $\begin{array}{l}\text { Doctoral Pro- } \\
\text { Seminar II (S) }\end{array}$ & $\begin{array}{l}\text { Evaluation for } \\
\text { Field Research } \\
\text { (S) }\end{array}$ \\
\hline $\begin{array}{l}\text { Action Research } \\
\& \text { Philosophy of } \\
\text { Science (C) } \\
2 \text { credits }\end{array}$ & $\begin{array}{l}\text { Quantitative } \\
\text { Data Analysis } \\
\text { (C) } 4 \text { credits }\end{array}$ & $\begin{array}{l}\text { Ethics in Field } \\
\text { Research (S) }\end{array}$ & $\begin{array}{l}\text { Teaching \& } \\
\text { Pedagogy in } \\
\text { Social Work (C) } \\
4 \text { credits }\end{array}$ \\
\hline \multirow[t]{3}{*}{$\begin{array}{l}\text { Action } \\
\text { Research } \\
\text { Mini-Project I } \\
\text { (P/R) }\end{array}$} & $\begin{array}{l}\text { Action Research } \\
\text { Mini-Project II } \\
\text { (P/R) }\end{array}$ & $\begin{array}{l}\text { Advanced } \\
\text { Assessment } \\
\text { for Action } \\
\text { Research (C) } \\
4 \text { credits }\end{array}$ & $\begin{array}{l}\text { Meta-Evaluation } \\
\text { and } \\
\text { Dissemination } \\
\text { (C) } 4 \text { credits }\end{array}$ \\
\hline & & $\begin{array}{l}\text { Advanced Data } \\
\text { Collection \& } \\
\text { Analysis (C) } \\
4 \text { credits }\end{array}$ & $\begin{array}{l}\text { Portfolio } \\
\text { Development } \\
\text { I (P/R) }\end{array}$ \\
\hline & & $\begin{array}{l}\text { Planning Major } \\
\text { Action Research } \\
\text { Project (P/R) }\end{array}$ & \\
\hline 4 Credits & 8 Credits & 8 Credits & 8 Credits \\
\hline $\begin{array}{l}\text { Year 2: Fall } \\
\text { Semester }\end{array}$ & $\begin{array}{l}\text { Year 2: Spring } \\
\text { Semester }\end{array}$ & Year 3: Summer & $\begin{array}{l}\text { Year 3: Fall } \\
\text { Semester }\end{array}$ \\
\hline $\begin{array}{l}\text { Dissertation } \\
\text { (8 credits) }\end{array}$ & $\begin{array}{l}\text { Doctoral Pro- } \\
\text { Seminar IV (S) }\end{array}$ & $\begin{array}{l}\text { Action Research } \\
\text { Supervision II } \\
\text { (P/R) }\end{array}$ & $\begin{array}{l}\text { Dissemination } \\
\text { Workshop \& } \\
\text { Portfolio } \\
\text { Preparation (S) }\end{array}$ \\
\hline $\begin{array}{l}\text { Doctoral Pro- } \\
\text { Seminar III (S) }\end{array}$ & $\begin{array}{l}\text { Action Research } \\
\text { Supervision I } \\
\text { (P/R) }\end{array}$ & $\begin{array}{l}\text { Action Research } \\
\text { Supervision III } \\
\text { (P/R) }\end{array}$ & \\
\hline $\begin{array}{l}\text { Academic } \\
\text { Writing and } \\
\text { Dissemination } \\
\text { (S) }\end{array}$ & $\begin{array}{l}\text { Portfolio } \\
\text { Development } \\
\text { II (P/R) }\end{array}$ & & \\
\hline \multicolumn{4}{|l|}{$\begin{array}{l}\text { Design and } \\
\text { Proposal } \\
\text { Writing (S) }\end{array}$} \\
\hline 8 Credits & & & \\
\hline
\end{tabular}

takes for the complete process to occur, but my experience is that four years is a "quick study," and the average time may be more like five or six years. Thus, to reduce delays in completing research, we decided to start team-based action research projects through the planning/research components of the curriculum. These team-based action research mini-projects begin immediately in the first semester, alongside the doctoral coursework and seminars. 


\section{Action Research and Community Engagement}

Action learning is a form of engagement that focuses on the utilization of existing knowledge and best practices to design and implement research projects that achieve important development outcomes and, at the same time, contribute to scholarly knowledge. Action learning is a central idea of the doctoral program: 1) Ethiopia is addressing serious social issues that require effective and high impact action to ameliorate these issues; 2) the university is a major resource to the country and, through its civic engagement, can create long-term action projects sustainable across generations of doctoral students to achieve beneficial community outcomes, while contributing to a global knowledge base; and 3) action projects will generate dissertation research that can potentially have an impact on the country's national poverty reduction, healthcare, and development agendas. As a core aspect of the doctoral program, action research imbues it with relevance, practicality, innovation, and a linkage between social theory and social work practice. We believe that this action research focus also makes this doctoral program distinctive within the range of programs existing internationally. An AAU doctoral degree in social work and social development is perhaps one of a kind, given this action research frame of reference and ethos of community/ civic engagement.

The planning/ research requirement of the doctoral program contributes to an emerging model of a university-community partnership for development (c.f., Soska \& Johnson Butterfield, 2005). Table 2 shows the process of our engagement with the Gedam Sefer community, an urban slum area in Addis Ababa. Our engagement started with a Community Assessment as part of a course assignment in the MSW program, followed by a small research study that assessed the skills and capacities of 100 poor women living in the community. For their field practicum, three students were placed in local government offices. Later, two MSW students carried out thesis research in the same community. When the doctoral program began, four students selected the Gedam Sefer community for ongoing engagement based on the Asset Based Community Development strategy (Kretzmann \& McKnight, 1993). The involvement of the doctoral students through action research in Gedam Sefer has led to increased formalization of the emerging university-community partnership through Action Research MiniProjects I and II and other Planning/Research segments of the curriculum. Currently, doctoral students are playing a leadership role in developing a largescale proposal and action plan for asset-based development with residents of the Gedam Sefer community.

The Gedam Sefer example illustrates how engaged research on the part of students and faculty in institutions of higher education, in partnership with local communities and organizations, can work collaboratively toward community change and build social interventions. We expect that the model of community engagement we are developing will lead to sustainable outcomes for improving the standard of living and quality of life of poor households in Ethiopia. Our model is also one means of responding to poverty by extending the teaching, service, and research capacity of a university in the United States and a university in Ethiopia to international development. As such, our partnership envelops the idea that partnerships are more than an exchange; they should exhibit a two-way transfer of 


\begin{tabular}{|c|c|c|}
\hline Timeline & Assignment & Projects in Gedam Sefer \\
\hline $\begin{array}{l}\text { Fall } 2004 \\
\text { MSW Student } \\
\text { Team }\end{array}$ & $\begin{array}{l}\text { Community } \\
\text { Assessment }\end{array}$ & $\begin{array}{l}\text { Community assessment on slum upgrading } \\
\text { program: The case of Gedam Sefer community } \\
\text { (Hagos, Gessese, Kebede, Abebe, Goshu, Barry, \& } \\
\text { Yared, 2004). }\end{array}$ \\
\hline $\begin{array}{l}\text { Summer } 2005 \\
\text { Research }\end{array}$ & & $\begin{array}{l}\text { Slum housing and income generation: Women's } \\
\text { role in obtaining public housing in Ethiopia } \\
\text { (Johnson Butterfield, Kebede, \& Gessese, 2005). }\end{array}$ \\
\hline $\begin{array}{l}\text { Fall } 2005 \\
\text { MSW Student } \\
\text { Team }\end{array}$ & $\begin{array}{l}\text { Community } \\
\text { Assessment }\end{array}$ & $\begin{array}{l}\text { Assessment of beggars community in Arada } \\
\text { Sub-city Addis Ababa (Mekonnen, Hailu, } \\
\text { Bezabih, Nega, Jonfa, \&B/Mesquel, 2005). }\end{array}$ \\
\hline Spring 2006 & $\begin{array}{l}\text { Field } \\
\text { Placement }\end{array}$ & $\begin{array}{l}\text { Three students placed in local government } \\
\text { office. }\end{array}$ \\
\hline $\begin{array}{l}\text { Spring } 2006 \\
\text { MSW Student }\end{array}$ & $\begin{array}{l}\text { Thesis Project- } \\
\text { MSW Program }\end{array}$ & $\begin{array}{l}\text { Social networks and communication among } \\
\text { female householders (Kebede, 2006). }\end{array}$ \\
\hline $\begin{array}{l}\text { Spring } 2006 \\
\text { MSW Student }\end{array}$ & $\begin{array}{l}\text { Thesis Project- } \\
\text { MSW Program }\end{array}$ & $\begin{array}{l}\text { Human strengths approach for sustainable } \\
\text { livelihood (Gessese, 2006). }\end{array}$ \\
\hline $\begin{array}{l}\text { Fall } 2006 \\
\text { Ph.D. Team }\end{array}$ & $\begin{array}{l}\text { Action Research } \\
\text { Mini-Project I }\end{array}$ & $\begin{array}{l}\text { Take research back to the community. Form a } \\
\text { Core Group to work with AAU and UIC in } \\
\text { university-community partnership. }\end{array}$ \\
\hline $\begin{array}{l}2007 \text { Ph.D. } \\
\text { Team }\end{array}$ & $\begin{array}{l}\text { Action } \\
\text { Research Mini- } \\
\text { Project II }\end{array}$ & $\begin{array}{l}\text { Workshop with Core Group on Family Based } \\
\text { Community Development (Kordesh, 2006). } \\
\text { Discuss university-community partnership. } \\
\text { Form a Technical Committee. }\end{array}$ \\
\hline $\begin{array}{l}2007 \text { Ph.D. } \\
\text { Team }\end{array}$ & $\begin{array}{l}\text { Planning a } \\
\text { Major Action } \\
\text { Research } \\
\text { Project }\end{array}$ & $\begin{array}{l}\text { Develop a major action research proposal in } \\
\text { collaboration with Core Group and Technical } \\
\text { Committee. }\end{array}$ \\
\hline
\end{tabular}

knowledge, methods, and practice skills. There is the opportunity to teach and learn from multiple partners. There is the opportunity to incorporate service into practice. And, there is the opportunity to engage in community development processes through action research.

\section{INTERNATIONALIZING DOCTORAL EDUCATION AT HOME}

I have some thoughts to share about what it might mean to internationalize doctoral education at one's home university. My comments relate to teaching in the doctoral program at the Jane Addams College of Social Work. As a doctoral program, we havenot made a decision to internationalize our curriculum. Yet, my experience with the doctoral program in Ethiopia is influencing my teaching at UIC. Global issues, large policy frameworks, and innovative practices from developing countries can be used to expose students to different ways of thinking about recalcitrant social problems in the United States. Here are some ideas:

- The UN Convention on the Rights of the Child (and others). Child welfare systems in the United States are built on the premise of "the best interests of the child." In developing countries (as well as other industrialized ones), 
the guiding principle for child welfare is the "rights of the child." Juxtaposing these two policy agendas will place child welfare policy in the United States in a global perspective. What would a child welfare system in the United States or Canada look like if our policies incorporated some or more of the idea of children's rights? Why hasn't the United States signed this declaration? Some discussion of this topic is included in the American Psychologist (c.f., Levesque, 1996; Melton, 2005; Murphy-Berman, Levesque, \& Berman, 1996).

- Comparative Analysis. Much social work research on poverty seems to lack comparative or international perspectives. Recently, I was privy to hear Dr. Jeffrey Sachs from Columbia University speak. His book, TheEnd of Poverty: Economic Possi bilities of Our Timebrings a global perspectiveto poverty policy (Sachs, 2005). Can one imagine such a title to a book? Who can imagine ending poverty? This book shows methods of comparative social policy by looking at the nations and GIS mapping of such things as the re-location of the textile industry, availability of Internet access, the malaria belts of the world, and so on. Healso features what some countries, India and Korea for example, have done to make progress toward ending poverty. As a macroeconomist, Sachs quips about his expertise in "long and short division," while calling for "clinical economics" - a perspective that takes researchers out to the field to examine poverty first-hand, then works directly with the poor to solve poverty from their perspectives, based on their strengths. There is some recent comparative work on welfare and the working poor population in the United States (e.g., Hoefer \& Midgley, 2006). The challenge for doctoral education in a global world is to advance policy research in social work to include comparative analysis. A good resource is Rihoux and Grimm (2006).

- Millennium Development Goals. Faculty, practitioners, and students of community practice in the developed world have paid little attention to the Millennium Development Goals (MDGs) set by the United Nations for decreasing global poverty by one-half by the target year of 2015. The eight goals of this relatively unnoticed framework range from halting the spread of HIV/AIDS, to ensuring environmental sustainability, from promoting gender equality and the empowerment of women to providing universal primary education. The MDGs form a blueprint agreed to by all the world's countries and all the world's leading development institutions. Sachs and UN Secretary Kofi Annan are working with some villages in Africa to see what it takes to meet the MDGs. What does it take for a village community to get out of extreme poverty, to position itself on the lowest rung of the economic ladder? Early findings indicate the following: medicine, a truck, one Internet hook-up, fertilizer, and bed nets. Bed nets treated with insecticide last for five years and cost fifty cents per person. They will prevent half of the malaria cases each year. One dollar will provide three days of malaria treatment for each infected person. Just one day of the U.S. military budget ( $\$ 150$ billion) will buy bed nets for all of Africa for five years. We could extrapolate this kind of thinking to community development efforts in communities with extreme poverty in the developed world. 
- Community Development. As a planned approach to improving the living conditions of poor and vulnerable populations around the world, community development responds to diverse global contexts. In the developing world, conditions of abject poverty noticeably require comprehensive and interdisciplinary approaches that include economic development, community participation, self-help, community organizing, capacity building, and so on from many disciplines and modes of intervention (Johnson Butterfield \& Chisanga, in press; Johnson Butterfield \& Korazim-Korosy, 2007). Creative efforts also seem to emerge in the developing world in an environment where less is sometimes more: there are less supports, but there may also be fewer barriers to getting things done by mobilizing human resources. Evidence from promising models and methods of community development include, among others, the effects of participatory asset-based approaches to alleviating poverty (O'Leary, 2006), the evidenced-based Rapid-Results Approach [http:// www.rapidresults.org/], and community conversations (Gebre \& Admassie, 2005).

- Action Research, Measurement, and Evaluation. Action research designs combine quantitative and qualitative methods (Reason \& Bradbury, 2006). Action research is also applicable to larger scale efforts at the community level, which are designed to foster participation, empower individuals, and so on. Providing doctoral students with methods applicable to larger systems should be a part of doctoral research training, so that within these larger systems, smaller studies can assess individual and group outcomes with particular measures at the psychosocial level. There is much work to be done by the World Bank in measuring empowerment (Narayan, 2005; Alsop, Bertelsen, \& Holland, 2006) and one can suppose that the international community is far ahead of our ability in social work to define and measure empowerment. Action research methods also teach teamwork and collaboration in research. By exposing our doctoral students to solid methods in action research, we can prepare them for team collaboration in research as junior faculty of the future.

My last comment presents challenges to deans and directors of doctoral education in social work. What would doctoral education look like if these two things happened?

- Expand Doctoral Education Within a Developing Country. The first challenge is for each doctoral program in the United States and Canada to become involved in expanding doctoral education within a developing country. This does not mean educating international students in doctoral programs at our home universities with the assumption that they plan to return to their homelands after completing their doctoral degrees. The partnership idea described in this article is just one of many potential and possible ways that doctoral programs contribute to building faculty capacity abroad. Higher Education for Development (HED) continues to provide USAID funding for such partnerships [http://www.hedprogram.org]. Online courses or other distance learning methods could be used to share doctoral courses 
and faculty from one country to another. These models represent a move within universities as a whole to "globalize" their systems in what is becoming a national movement towards globalizing the campus. For example, since the mid-1990s, a number of large universities have opened new campuses in other countries, particularly India, the Middle East, and Southeast Asia, with new growth occurring in China, India, and Central Asia. These branch campuses move beyond a place to send students for study abroad but are designed to educate the population from the host country (MacBurnie \& Ziguras, 2005). Social work doctoral education should be at the forefront and lead the way toward internationalizing the profession.

- Preparing Doctoral Students for International Work. Internationalizing doctoral social work education in the United States and Canada would mean that each new recipient of the degree is well prepared to include international perspectives in his or her teaching and research. By internationalizing doctoral education, can we break out of the old paradigm that cautions our junior faculty not to pursue international work until they get tenure? Can the new paradigm bethat those junior faculty who are involved internationally in their research and service are more competitive in the job market and tenure review processes? Can we imagine a world of social work faculty and researchers with doctorate degrees who are involved in the reality of the global world in some way? This does not mean that everyone has to travel abroad. We know, for example, that the Internet can put us in direct contact with the world. The world is flat. Comparative policies can be taught in the classroom. Learning from innovative practices in other countries has the potential to inform the profession, its current methods, and standards. Scholarship can build on and help build the best practices-not only in our home countries-but in those countries throughout the world that share our professional work.

\section{References}

Alsop, R., Bertelsen, M., \& Holland, J. (2006). Empowerment in practice: From analysis to implementation. Washington, D.C.: The World Bank.

Friedman, T.L. (2006). Theworld isflat: A brief history of thetwenty-first century. NY: Farrar, Straus and Giroux.

Gebre, A., \&Admassie, Y. (2005, December). Community conversations on HIV/AIDS pilot projects in Alaba and Yabello: Assessment of the methodology. Addis Ababa, Ethiopia: United Nations Development Programme.

Gessese, A. (2006). Human strengths approach for sustainable livelihood. MSW Thesis. School of Social Work, Addis Ababa University.

Getu, M. (2005). Report of the Associate Dean of the College of Social Sciences. Addis Ababa University, Addis Ababa, Ethiopia.

Hagos, A., Gessese, A., Kebede, W., Abebe, S., Goshu, M., Barry, A., \&Yared, B. (2004, October). Community assessment on slum upgrading program: The case of Gedam Sefer community. Unpublished report. School of Social Work: Addis Ababa University. 
Healy, L.M., Asamoah, Y., \& Hokenstad, M.C. (Eds). (2003). Models of international collaboration in social work education. Washington, D.C.: CSWE.

Hoefer, R., \& Midgley, J. (Eds.). (2006). International perspectives on welfare to work policy. Bimington, NY: The Haworth Press.

International Association of Schools of Social Work (IASSW). (2004). Global Standards for Social Work Education and Training. Retrieved 9/9/06 from http://www.iassw-aiets.org/.

Johnson Butterfield, A.K., \& Chisanga, B. (in press). Community development. In T. Mizrahi and L.E. Davis (Eds.) Encyclopedia of Social Work, 20 ${ }^{\text {th }}$ Edition. NY: Oxford University Press.

Johnson Butterfield, A.K., \& Korazim-Korosy, Y. (Eds.). (2007). Interdisciplinary community development: International perspectives. Bimington, NY: The Haworth Press, Inc.

Johnson Butterfield, A.K., \& Linsk, N. (2005). The Social Work Education in Ethiopia Partnership (Project SWEEP). Final report to the Association Liaison Office for University Cooperation in Development (ALO/USAID). Chicago, IL: Jane Addams College of Social Work, University of Illinois at Chicago. http://www.aboutsweep.org.

Kebede, W. (2006). Social networks and communication among femalehouseholders. MSWThesis. School of Social Work, Addis Ababa University.

Kordesh, R.S. (2006). Restoring power to parents and places: Thecasefor family-based community development. NY: iUniverse, Inc.

Kretzmann, J.P., \& McKnight, J.J. (1993). Building communities from theinside out: A path toward finding and mobilizing a community's assets. Chicago: ACTA Publications.

Levesque, R.J.R. (1996). International children's rights can they make a difference in American family policy? American Psychologist, 51(12), 1251-1256.

MacBurnie, G., \& Ziguras, C. (2005). The international branch campus. Institute of International Education, New York. Accessed 9/26/06 at http:// www.iienetwork.org/page/ 84656/.

Matshalaga, N.R., \& Powell, G. (2002). Mass orphanhood in the era of HIV/AIDS. British Medical Journal, 324 (January), 185-186.

Mekonnen, A., Hailu, D., Bezabih, E., Nega, M., Jonfa, M., \& B/Mesquel, W/S. (2005, October). Assessment of beggar's community in Arada Sub-city Addis Ababa. Unpublished report. School of Social Work: Addis Ababa University.

Melton, G.B. (2005). Building humane communities respectful of children: The significance of the Convention on the Rights of the Child. American Psychologist, 60(8), 918-926.

Midgley, J. (1990). International social work: Learning from the third world. Social Work, 35(4), 295-301.

Murphy-Berman, V., Levesque, H.L., \& Berman, J.J. (1996). U.N. Convention on the rights of the child a cross-cultural view. American Psychologist, 51(12), 1257-1261.

Narayan, D. (Ed.). (2005). Measuring empowerment: Cross-disciplinary approaches. Washington, D.C.: The World Bank.

O'Leary, T. (2006). Asset based approaches to rural community development: Literature review and resources. International Association for Community Development for Carnegie Trust UK. http://rural.carnegieuktrust.org.uk/ files/ rural/Asset-based\%20approaches\%20-IACD.pdf.

Reason, P., \& Bradbury, H. (2006). Handbook of action research. Thousand Oaks, CA: Sage.

Rihoux, B., \& Grimm, H. (Eds.). (2006). Innovative comparative methods for policy analysis: Beyond the quantitative-qualitativedivide NY: Springer Publishing Co.

Sachs, J.D. (2005). Theend of poverty: Economic possibilities for our time NY: The Penguin Press.

Shinn, David H. (2001, July). HIV/AIDS in Ethiopia: The silence is broken; The stigma is not. Center for Strategic and International Studies, Africa Program. Retrieved February 9, 2008 from http://www.csis.org/media/csis/pubs/anotes_0107.pdf.

Smith, B., with Amin, S. (1998). The man who moved the world: The life and work of Mohamed Amin. Nairobi: Camerapix Publishers International.

Soska, T.M., \& Johnson Butterfield, A.K. (Eds.). (2005). University-community partnerships: Colleges and universities in civic engagement. Bimington, NY: The Haworth Press, Inc. 
Tasse, A., \& Getu, M. (2006, July). Rationale and course descriptions for a doctor of philosophy (Ph.D.) in Social Work and Social Development at the Graduate School of Social Work, Addis Ababa University. Available at: http:// www.aboutsweep.edu.

World Bank. (2007). Ethiopia Country Brief. http://www.worldbank.org/afr/et/ctry_brief.htm.

\section{Author's Note:}

Address correspondence to: Professor Alice K. Johnson Butterfield, Jane Addams College of Social Work, University of Illinois at Chicago, 1040 West Harrison Street (M/C 309), Chicago, IL 60411, USA. e-mail: akj@uic.edu.

This article is based on keynote speeches given at the Group for the Advancement of Doctoral Education (GADE), Calgary, Canada, on October 13, 2006; and the $11^{\text {th }}$ Annual Ph.D. Spring Symposium at the School of Social Work, Indiana University, Indianapolis, Indiana, on April 20, 2007. This article is dedicated to the memory of Dr. Seyoum Gebre Selassie, former Dean and Professor Emeritus at Addis Ababa University. His vision for the rebirth of social work education in Ethiopia continues to guide our work. It is one of the great privileges of my professional life to have worked with him and to have learned so much from him. 